\title{
Teaching Foreigners the History of Russia in Context of Integration Processes of Cis Countries ${ }^{1}$
}

\author{
Arslanov Rafael Amirovich \\ Ph.D. in History, Professor, Professor of the Department of History of Russia, \\ Peoples' Friendship University of Russia (Russia) \\ Email: ars_raf@mail.ru

\section{Kozmenko Vladimir Matveevich} \\ Ph.D. in History, Professor, Head of the Department of History, \\ Peoples' Friendship University of Russia (Russia) \\ Email:v.kozmenko@gmail.com
}

\section{Doi:10.5901/mjss.2015.v6n1s2p54}

\section{Abstract}

The article considers the significance of teaching the course of history for foreigners coming to Russia. It is noted that the studying of traditions and culture of the host country helps them to adapt to the social life of Russia. Besides, it is emphasized that the general historical knowledge creates the condition for overcoming ethnic and cultural barriers and it becomes one of the spiritual factors of Eurasian integration. Particular attention is paid to the content of the course in which specific historical examples show that Russia was founded and developing thanks to the unity and interaction of different nations, traditions and cultures.

Keywords: integration, localism, ethnic and cultural isolation, migrant workers, course of Russian history.

The significance of addressing the problem of teaching migrant workers the history of Russia is determined by the necessity, on the one hand, to adapt them to the sociocultural conditions of life of the modern Russian society, and, on the other hand - to overcome the ethnic and cultural isolation and create certain spiritual factors to ensure integration processes in the post-Soviet space.

It is known that most migrants coming to work in Russia are young people from the former Soviet republics of Central Asia. Many of them know nothing about the past of Russia, its culture and traditions and often can't speak Russian. Studying the history of the host country includes acquaintance with its major milestones of development, traditions and culture, without which it is impossible to gain understanding of their surrounding sociocultural realities, and, consequently, to adapt to the life of modern Russian society. Moreover, having gained general knowledge about Russia, which at different times was composed of now sovereign post-Soviet states, foreign citizens can see the intertwining destinies of the Russian and other nations in the past, which can have an impact on the integration processes in the present.

However, it should be noted that in modern Russian society there is no consensus not only on teaching migrants any courses, but even on the necessity of attracting them to the country. Opponents of the necessity of acquainting foreigners with the history of Russia proceed from the assumption that gaining information which is beyond their pragmatic interests is an excessive and useless burden for people unprepared for studying. In their opinion, taking tests and checking knowledge in history are not only an onerous ordeal requiring considerable amount of money and time, but also an ineffective project discrediting the country's governmental institutions and teaching staff. Thus, the opponents of introducing the course of history of Russia from the Human Rights Council under the President of the Russian Federation concluded that "... forced studying of history by migrants and the level of their knowledge of history will obviously be unacceptably low, even for adaptation" (Belkin A., 2014).

However, during a heated discussion there prevailed the view of the necessity of teaching foreigners not only the Russian language, but also the basics of history and law of Russia. It was noted that it was "the attractiveness of

1 Scientific publication has been made with the support of the Ministry of Education and Science of the Russian Federation in the framework of the scientific and methodological works in 2014 № 10.9063.2014 
education and its significance" that could become an important factor of overcoming migrants' social isolation; and mastering the Russian language and the basics of national culture could be sine qua non of their life and work in Russia. The fact is that acquainting with the basics of Russian history will help to shape foreigners' respect for the Russian national values, traditions and laws, state symbols of the Russian Federation, culture of its nations, without which it is impossible to ensure their interaction with the local population, to create an atmosphere of inter-ethnic tolerance.

As a result, on April 20, 2014 there was adopted Federal law (№74 FZ) "On the Legal Status of Foreign Citizens in the Russian Federation", under which migrant workers (with the exception of highly qualified specialists) are to take exams on the Russian language, History and Fundamentals of legislation of the Russian Federation.

It should be also taken into account that teaching foreign citizens history is necessary for the Russian society. The fact is that a person ignorant of local traditions and customs may have problems in unfamiliar social circumstances both in their relationships with people around and in their professional activities. Most conflicts between Russians and migrants typically occur on grounds of mutual misunderstanding arising from ignorance of national traditions and cultures.

The course of history is aimed at minimizing the negative consequences of the adaptation process of foreigners, at creating spiritual prerequisites not only for local, but also, potentially, for Eurasian integration.

It should be also taken into consideration that after the USSR collapse in the newly independent states there were created textbooks on national history, in which "with varying degrees of detachment from the historical reality and intensity of anti-Russian sentiment, textbook writers began to shape often mythologized notions of historical processes on the territories which got new statehood" (Kerov V.V. , 2013). Thus, Kievan Rus' as the authentic East Slavic state, which belonged to the European civilization and became the cradle of modern Ukraine, is opposed in Ukrainian textbooks to Asian Vladimir-Moscow despotism, which emerged as a result of Finno-Slavic-Turkic synthesis.

According to Ukrainian historian A.Portnov, "Ukrainian educational mainstream, especially the school one, is a national narrative. It is the history of Ukrainians, identified with the history of Ukraine and the Ukrainian state. History was defined as a gradual development of different forms of Ukrainian statehood from Kievan Rus' to the present day. Through Zaporozhye Cossacks, through the issue of relations with Poland, Lithuania, through the Russian empire, which, of course appears as an oppressor..." ( Portnov A.,2013).

Thus, in a number of post-Soviet countries the school history curriculum is aimed at the formation of pupils' extremely negative perception of the Russian state and Russian people, which turns history into a tool of hatred and violence. For example, in Ukraine after the USSR collapse there has grown up a generation which, largely under the influence of the acquired knowledge of history, began to perceive Russia as a colonial empire which enslaved "the freedom-loving, talented Ukrainian people", as the source of its misery and sufferings (Lessons of Ukrainian). Moreover,Ya. Dashkevich, Ukrainian PhD in History, accused Russia of "theft" of national history and attempts to distort the Ukrainian national consciousness. According to him, "Moscow, and later Russian, tsars realized that without great past time it is impossible to create a great nation, a great empire. For this purpose it was necessary to decorate their historical past and even assign someone else. Therefore, Moscow tsars, starting with Ivan IV (the Terrible), set the task to appropriate the history of Kievan Rus', its glorious past and create official mythology of the Russian empire." According to the historian, the purpose of this "assignment" was complete destruction of Ukraine - its history, language and culture... For centuries the idea has been instilled into people's minds that the Russian state and the Russian nation originate from the Grand Duchy of Kiev; that Kievan Rus' is the cradle of three fraternal nations - Russian, Ukrainian and Belorussian; that under the law of "big brother", Russians have the right to the heritage of Kievan Rus'. This miserable lie is still used by Russian historiography and Russian statesmen, as well as the "fifth column" in Ukraine, which includes the Communists and almost all members of the Party of Regions in the Verkhovna Rada of Ukraine" (Dashkevich H., 2011).

It is with the help of historical science that Ukrainian young people acquired the sense of national exceptionalism, hatred for "Moskals", who must repay their historical debt to Ukraine. Thus, the teaching of history has become a means of not only transforming a part of youth into an obedient tool of certain national-political forces, but also of setting it against Russia as the main culprit of all tragic events of modern Ukraine.

In some Central Asian republics, for example, Uzbekistan, school history curriculum ignores the close relations of their nations with Russia. Even their common fight during the Great Patriotic war is ignored. The pre-revolutionary Russia, and later the USSR, appears as an imperialist state, which used the Central Asian region as a source of cheap raw materials, suppressed their national liberation aspirations and eventually doomed them to economic backwardness. Thus, the Uzbek textbook writers try to prove that the entire Central Asian region is "Uzbek", and the existence of other independent states there became the result of "conspiracy", organized by Russian tsarism and Soviet bolshevism, which are presented as the main enemies of the "Uzbek independence" (Alimova D.A., 2010). The textbook states that "the conquest of the Central Asian khanates by the Russian Empire led to the decline in the region, a serious lag in many fields from highly developed countries, the trampling of national values. The colonial policy in the region was notable for 
the fact that it was beneficial for the empire to keep the most part of the local population illiterate and backward. Cotton processing, mining, railways and other industries, which emerged during the colonial rule, were aimed at meeting the needs of the tsar's Russia. Export of the products of these enterprises created an insurmountable barrier for profit earning and improving their production process. Forced competition with imported manufactured goods from Russia lead to the ruin and crisis of handicraft production in Turkestan, which in turn even further increased the region dependence on Russia (Bailey Maxim, 2011). By the way, the migration processes and a surge of migrant workers from the CIS countries to modern Russia are interpreted by official historiographers of some Central Asian republics as a consequence of their colonial past.

As a result, foreign citizens who came to Russia with formed concepts of its "historical crimes", a biased view of the country's history, culture and modern policy, will a priori perceive the surrounding social environment at least warily. They won't be able to treat people of a different culture with tolerance, which will be an obstacle not only to their adaptation to the Russian realities, but also to their communication with other migrant communities.

Thus, the basic knowledge of Russian history helps foreigners not only to objectively consider the past of the host country, to comprehend the true substance of the relationship of its historic centre and national provinces, but also to form the system of values, tolerant perception of people of other nations and confessions which is indispensable to their participation in labour activities and intercultural cooperation on the territory of Russia. Mastering the course of history, leading to the formation of general knowledge, can influence the shaping of such a behavior imperative which will help to unify people of different ethnic groups and religions and overcome their ethnic and cultural discord. Self-awareness through the comprehension of the common historical destiny and the part of civilization unity creates certain spiritual prerequisites for the reconstruction of this unity. Thus, knowledge of the Russian language and history becomes the main means of not only social identification, but also overcoming the barriers separating migrant communities from the local population as well as from each other.

Thus, mastering the course of history helps foreigners to find in the past the common roots of the development of their nation and the Russian one, to realize the facts of their destinies intertwining, which is the most important spiritual factor of the post-Soviet space integration.

On the whole, studying history of Russia involves the creation of certain spiritual prerequisites for the balanced social and cultural adaptation of foreign citizens in the Russian society, and, in the long term, when it comes to people from Central Asian republics, for Eurasian integration. Undoubtedly, the knowledge of the most important facts and events of Russian history will contribute not only to foreigners' adequate perception of the modern Russian realities, correct understanding of the sociocultural and political processes in Russia, but also their successful self-realization in the modern Russian society. Without knowledge of the culture and traditions of the people on whose territory one lives it is impossible to overcome the ethnic and cultural isolationism, to understand the processes in the society.

Taking into account the complexity of mastering the course of history, particular attention was paid to the simplicity and conciseness of the historical material presentation. Naturally, while creating the training module there was used the methodological experience of teaching foreign citizens the history of Russia, accumulated for many years (Kolosnitsyna G.V). But the peculiarities of the audience and low level of their humanities background forced to search for appropriate methods. Thus, in the syllabus there were introduced video and audio materials of great historical significance; the key topics in the created textbook were preceded by linguistic introduction and glossary, the study of which helps to better understand the facts (Kozmenko V.M., 2014). But special emphasis was laid on the course content aimed at not only stimulating the learning process, but also contributing to the solution to integration problems.

The principal lines throughout all course topics are identification and emphasis of the multinational character of Russia, statement of the interrelations of Russian people with other nations, which at different historic stages became regions of the Russian state; creation and dissemination of cultural values determining not only the national identity, but also spiritual interaction between peoples of Russia.

Particular attention in the course is paid to the events, in which there clearly manifested themselves the best features of the Russian people: diligence, patriotism, ability to sacrifice their personal good to achieve common goals, desire to protect the week and help those in need, ability to overcome natural, economic, political problems etc. All these features played a crucial role not only in the formation of a powerful state and unification of various nations within its borders, but also in the creation of great culture, which influenced their historical development.

The whole history of Russia, the biggest multinational and multi-religious country in the world, is riddled with multifaceted relationships of different nations. Naturally, in the course content special emphasis is laid on the interaction of nations of Russia, their cultures and religions; there is stressed the necessity of strengthening economic, social and cultural relations as one of the decisive factors of the post-Soviet integration. The very formation and development of the ancient Russian state (Kievan Rus') was the result of the efforts of various nations, interethnic fusion, based on mutual 
interest and mutual cooperation of Slavic farmers, Turkish cattle-breeders, Finnish hunters, Norman warriors and merchants. Emphasizing the multinational character of the Russian state, which was initially formed as symbiosis of the Slavic, Turkic, Finno-Ugric components, the attention in the course of history is focused on the factors that united different peoples which inhabited Russia. First of all, it is cultural contacts, interaction in the economic and trade fields, mutual influence in daily life, religious tolerance, absence of Russian people's sense of national and, especially, of racial superiority.

Naturally, there was feud between tribes and peoples, there occurred clashes, but mutual interest in cooperation prevailed, determining the integration processes and becoming the basis of the formation of the centralized Russian state on the territory of Eastern Europe. Later on, interethnic interaction became one of the factors of the creation and development of the Russian empire (Aleksandrov V.A.).

Particular attention in the course of history is paid to the mass heroism of the peoples of Russia in the liberation wars, especially in the Great Patriotic War of 1941-1945. It is emphasized that the common feat, being an example of public spirit and self-sacrifice in the name of the Fatherland, not only rallied the peoples of the country, but also, surviving in memory, can serve as a factor of their spiritual rapprochement today. Thus, the revelation of facts of peoples' unity in the struggle against foreign enemies, of significance of mutual aid and support in the hard years of economic and political turmoil in the past creates a historic background for their integration at present.

The course of history also emphasizes the multi-religious nature of the Russian state, there are given examples of cooperation between the Orthodox, Muslims, people of other religions in defending Russia from enemies, in creating cultural monuments, in developing science and education. Foreigners should get interested in the significant fact that up to a third of the Russian nobility had Turkic roots (Petrov. P.N., 2007). It should also be noted that the formation of the Soviet elite occurred as a result of social and professional rather than national criteria of selection.

In the course of Russian history there are materials refuting the conclusions and opinions of several authors of history textbooks on negative consequences of the "colonial past", for example, of Central Asian republics. Based on historical facts, there is substantiated the idea that different nations' staying within the Russian state, and later the Soviet Union, on the whole had a positive effect. First of all, there was provided security from external enemies, in some regions there was eliminated slavery and stopped internal turmoil, created the conditions for the economic and cultural development, dissemination of education, healthcare, etc.

Thus, the keynote of teaching the CIS countries citizens the course of history became the idea that Russia was founded by people of different nations and religions, and the established tradition of cooperation, receiving a new impetus of development, can become one of the decisive factors of their spiritual and economic integration. As a result of studying history, a foreign citizen is to get a sense of his in demand in Russian society, on the one hand, and on the other hand the responsibility for the future relations between nations.

Ultimately, knowledge of Russian history and culture will help a foreign citizen to work out a strategy of tolerant interpersonal interaction in accordance with the traditions and customs of the Russian society, the experience of interethnic cooperation, permeating the whole history of the country.

Moreover, the study of the history of Russia will help to withstand some negative consequences of the globalization process, leading, for example, to the loss of some cultural and national traditions, the devaluation of family values, unconditional friendship and mutual assistance, the rise of immorality and the dominance of mass culture.

Thus, the study of the major events of the past of Russia is determined by the need to establish internal connections in its history, determining the role of peoples' cooperation in the past of the country, without which it is impossible to comprehend the national identity, on the one hand, and on the other hand - to create spiritual prerequisites for post-Soviet integration.

Mastering the course of history should help a foreign citizen not only to perceive the world in the diversity of its cultures and civilizations, but also see the significance of their interaction.

\section{References}

Aleksandrov V.A. Russian government policy on the national issue (mid XVII-XVIIIth centuries.) // National policy in Russia. - M., 1992 Book. 1: Middle of XVII - end of XVIIIth century; Vdovin A.I., Zorin V.Y.,

Nikonov A.V. Russian people in national politics. XX Century. - Moscow, 1998; Kappeler A.Russia - a multinational empire. Emergence. History. Decay. - M., 2000; Tsimbaev N.I. Russia and Russians (the national issue in the Russian Empire) // MGU Bulletin. Ser. 8 - History. 1993. - № 5 and others.

Alimova D.A. (2010). "History of Uzbekistan" for the 9th class of secondary schools. - Tashkent, $160 \mathrm{p}$.

Bailey Maxim, (2011). "New History" of Uzbekistan: Mythology of Karimov's times. 27.09.2 011 14:16 msk, Fergana. ). [online] Avaible : http://www.fergananews.com/articles/7112 (September 27, 2011) 
Belkin A., (2014), Migrants do not need to know neither history of Russia, nor its law. [online] Avaible: http://www.km.ru/vrossii/2014/01/10/sovet-federatsii-fs-rf/729492-migranty-ne-dolzhny-znat-ni-istoriyu-rossii (January 10, 2014)

Dashkevich H., (2011). As Muscovy stole the history of Kievan Rus-Ukraine (report of PhD in History). [online] Avaible: http://universum.lviv.ua/journal/2011/6/dashk.htm.

Kerov V.V.,(2013). "Ukraine-Rus", "Finno-Ugric colony" and the Belarusian national traditions: the justification of state sovereignty in the official textbooks of the national history of Ukraine and Belarus / Herald Peoples' Friendship University. A series of "History of Russia". S. 124.

Kolosnitsyna G.V., Castellina I.P. From Rus to Russia. (Textbook of Russian history of IX-XIIIth centuries for foreign students. - MSU. Center for International Education. 2004 - 96 p.; Castellina I.P., Parfyonova I.A., Ragulskaya G.V. History of Russia. Manual for foreign students. - MSU. Center for International Education. 2005 - 109 p.; Tretyakov I.A. History of Russia from ancient times until February 1917. Part I. Manual for foreign students and students of the Faculty of Philology of the preparatory branch / edited by prof. Vyunova A.Y. - M., 2009 - 96 p.; Tretyakov I.A. History of Russia in the XX - XXI: Textbook for foreign students. - Part II. M., 2012 - 96 p. etc.

Kozmenko V.M., Dolzhikova A.V., Arslanov R.A, Moseykina M.N., Rumyantseva N.M., Guseva I.S.(2014). History of Russia: a manual for training of foreign citizens for exam- Moscow: People's Friendship Universityof Russia,-173 p.

Lessons of Ukrainian. What students are taught in Ukrainian history textbooks. [online] Avaible: Http://sputnikipogrom.com/russia/ua/ 10331/ua-textbooks; Sernik I. Russia in Ukrainian history textbooks // http://www.contrtv.ru/ common/1838.

Petrov. P.N.(2007). History of the Russian nobility families.

Portnov A.,(2013). About the Problems of Post-Soviet Historical Science in Ukraine. [online] Avaible: http://www.polit.ru/article/ 2013/03/31/ps_sc20_portnov. 